\title{
SEGÉLYCSOMAGOK KISZÁLLÍTÁSA KATASZTRÓFA UTÁN TEHERAUTÓ-DRÓN TANDEMMEL
}

\author{
KOVÁCS GERGELY, VIZVÁRI BÉLA
}

\begin{abstract}
A humanitárius logisztika a logisztika minden olyan ágát felöleli, amit azért müvelnek, hogy embereken segítsenek. Ezen belül fontos részterület a katasztrófák után a segélycsomagok eljuttatása a rászorulókhoz. A szállítási technológia változásával itt újabb matematikai feladatok merülnek fel. Jelenleg a legfontosabb technológiai újítás a pilóta nélküli légi jármüvek, azaz drónok alkalmazása. Ebben a cikkben az utazó ügynök feladat egy olyan változatát tárgyaljuk, amelyben egy teherautó és egy drón alkotta páros látja el egy katasztrófa sújtotta vidéki, azaz nem sűrű úthálózattal rendelkező nagyvárosi terület igényeit. A drónt két repülése között a teherautó viszi magával. A drónt a teherautón szállított segélycsomagokból töltik fel. Maga a teherautó kiszolgálja mindazokat a pontokat, amelyeken keresztül halad. A megoldás két fontos előnye, hogy azok a helyek is elláthatók, amelyek az utak megrongálódása vagy egyéb ok miatt máshogy nem érhetők el, és a páros rövidebb idő alatt tudja a segélyt eljuttatni a rászorulókhoz.
\end{abstract}

\section{Bevezetés}

Minden évben számos katasztrófa történik a világban. Földrengés és árvíz sok területet sújt. A katasztrófa utáni időszak egyik legfontosabb feladata az, hogy segélyt nyújtson a rászoruló embereknek. A szállítás módja fontos, és a körülményektől függ. Például a hurrikán esetében annak helye és ideje ismert. Mielőtt a hurrikán lecsapna, a segélycsomagokat, beleértve az élelmiszert is, raktárakba lehet szállítani. A hurrikán alatt azonban le kell állítani a szállítást. A földrengés előfordulási helyei ismertek. Így már a katasztrófa előtti időszakban létre lehet hozni olyan segélyszervezetet, amely szállítási kapacitással is rendelkezik. A szervezet tulajdonában lévő jármüvek teherautók és drónok is lehetnek [12]. A jármüvek közül a helikopterek nagyon hasznosak, mert sokféle célra felhasználhatók. Azonban nem lehet jó helikopterflottára számítani a katasztrófa utáni időszakban, kivéve, ha nagyon erős a katonai részvétel a mentésben [9]. A közlekedés nehezebb, ha vidéki területet sújt a katasztrófa, mintha egy nagyvárost, mert az utóbbiban sok a párhuzamos út. Világosan mutatta ezt 2004-ben Aceh [9] és 2011-ben a 
Van-tó melletti földrengés esete [17]. A szállítási távolság ilyen esetben hosszú, és kevés a használható út. Továbbá lehetnek olyan helyek, amelyeket nem lehet megközelíteni közúton. Csak drónokból álló szállítási rendszer használható a városokban, de vidéki térségben nem feltétlenül tud minden igényt kielégíteni a nagyobb távolságok és a drónok korlátos maximális repülési ideje miatt, amit állóképességnek is nevezhetünk. Ilyen esetekben kombinált szállítási mód lehet a megoldás. Már létező műszaki megoldás a következő. Egy nagy teherautó szállítja a segélycsomagokat. A tetején van egy drón. A teherautó szolgálja ki azokat a helyeket, amelyeket útja során érint. A teherautó útvonalától távol eső helyeket a drón szolgálja ki. A drón korlátozott állóképességgel rendelkezik, de csomaggal és üzemanyaggal való újratöltése technikai szempontból könnyen megoldható a teherautóról. A kombinált megoldásnak számos előnye van, így például kevesebb drón szükséges annál, mintha minden szállítást drón végezne.

Amikor egy teherautó-drón tandem küldetést hajt végre, akkor először az általuk kiszolgálandó helyeket kell kiválasztani. A közös küldetés ütemezése során külön kell választani a teherautó és a drón által meglátogatott helyeket. Ezen kívül minden küldetést optimalizálni kell. A tandem egy központi raktárból indul, és ugyanoda tér vissza. Ezért a matematikai problémát az angol nyelvü irodalom gyakran jelöli TSP-D-vel, ami a drónnal kiegészített utazó ügynök feladatot (travelling salesman problem with drones) jelenti. A problémát [1] és [11] vezette be. Az utóbbi közölt egy egzakt modellt, ami azonban igen nagyméretü lehet. [19] hasonló modellt dolgozott ki, ami hatékonyabb és 12 pontig müködik. Dinamikus programozáson alapuló hatékony megoldási módszer található [2]-ben. A [5] és [7] evolúciós algoritmust dolgozott ki a feladat megoldására.

\section{Az utazó ügynök feladatról}

Az utazó ügynök feladat (travelling salesman problem, TSP) ugyan kezelhető egzakt modell nélkül [2], ebben a dolgozatban a garantált optimum elérésére törekszünk.

A TSP hosszú múltra tekint vissza. A feladatot 1832-ben definiálták [14]. A TSP-t ismerték és tudományos beszélgetésekben tárgyalták, de az első matematikai modellre 1954-ig kellett várni [4]. Érdekes módon ez a mai napig az egyik legnépszerübb és a számítási szempontból leghatékonyabb modell. Jól ragadja meg a probléma kombinatorikus természetét. Azonban más modellekkel ellentétben nincs eszköze a körút idejének elemzésére. Másik hátránya, hogy exponenciálisan sok feltételt tartalmaz. A gyakorlatban iteratív módon oldjuk meg úgy, hogy minden iterációban egy relaxált feladat optimális megoldását keressük meg. A relaxáció abban áll, hogy az összes feltétel helyett csak azok egy részhalmazát követeljük meg. Ha a pillanatnyi optimális megoldás nem elégíti ki az összes feltételt, akkor egy megsértett feltételt adunk a feladathoz. Ez a megközelítés sok matematikai eredmény elérését tette lehetővé, melyek legnagyobb része kívül 
esik ezen a dolgozaton. Később a TSP számos más modelljét találták meg [15]. Elméleti összehasonlítás alapján [15] arra a következtetésre jutott, hogy a [4] modellje a két leghatékonyabb egyike.

A számításokban másik népszerű modell a [10]. Egyszerű módszert alkalmaz az idő múlásának leírására. Minden városhoz tartozik egy döntési változó, amely azt adja meg, hogy a város hányadik a körútban a kiindulási pont után, mely utóbbinak 0 a pozíciója. Más modellek is használhatók a számításhoz. A különböző modelleket nem hasonlították össze alaposan abból a szempontból, hogy a belőlük származó optimalizálási feladatok mennyire hatékonyan oldhatók meg.

Az ebben a dolgozatban tárgyalt modell alapja a Miller-Tucker-Zemlin-modell, vagy röviden az MTZ-modell. A modellt először általános irányított gráfok esetében fogalmazzuk meg. A meglátogatandó pontok halmaza $N:=\{0,1, \ldots, n\}$, ahol 0 a kezdőpont. A körút itt kezdődik és fejeződik be. A $j$ pont távolsága az $i$ ponttól $d_{i j}$. A távolságról nem tesszük fel, hogy szimmetrikus. A legfontosabb döntési változók a következők:

$$
x_{i j}= \begin{cases}1, & \text { ha az ügynök } i \text {-ből közvetlenül } j \text { városba utazik, } \\ 0 & \text { különben. }\end{cases}
$$

A feltételek első két csoportja egyszerü. Az ügynöknek minden várost el kell hagynia, ami az alábbi egyenletekkel fejezhető ki

$$
\forall i \in N: \sum_{j \in N, j \neq i} x_{i j}=1 .
$$

Ehhez hasonlóan meg is kell érkeznie minden városba

$$
\forall j \in N: \sum_{i \in N, j \neq i} x_{i j}=1 .
$$

Sajnos a (2) és (3) feltétel nem elegendő a körutak pontos leírására, mert kisebb köröket is megenged.

Így további feltételekre van szükség, melyek kizárják a teljes körútnál kisebb köröket. [4] ezen a ponton sok exponenciális korlátozást vezet be. Az MTZ-modell más. Bevezet $n$ új, folytonos változót és ezekre vonatkozó $O\left(n^{2}\right)$ számú feltételt. A változók a gráf csúcsaihoz tartoznak a kiindulási pont kivételével, melyhez nem tartozik új változó. Lent azonban kiderül, hogy a feltételek miatt ezek csak egész értékeket vehetnek fel. Legyen $u_{j}$ az, hogy a $j$ város hányadik a körútban a kezdőpont után. Az új feltételek a következők:

$$
\forall j \in N, j \neq 0: 1 \leq u_{j} \leq n
$$

és

$$
\forall i, j \in N, i \neq j, i, j \neq 0: u_{i}-u_{j}+n x_{i j} \leq n-1
$$


Vegyük észre, ha $x_{i j}=0$, akkor (4)-ből következik, hogy (5) teljesül. Ha $x_{i j}=1$, akkor (5) arra egyszerüsödik, hogy

$$
u_{i}+1 \leq u_{j} .
$$

Innen azonnal következik, hogy az $u_{i}$ változók csak az egész számokat vehetik fel 1 és $n$ között. Ha van kisebb kör, akkor legalább két ilyen létezik. Az egyik kisebb kör nem tartalmazza a kiindulási pontot. (6) szerint ezen kisebb kör mentén az $u_{j}$ változók értéke szigorúan növekszik. Tegyük fel, hogy az ügynök ezen a kisebb körön indul a $k$ várostól. Amikor visszatér ugyanebbe a $k$ városba, $u_{k}$-nak nagyobbnak kell lennie, mint a kör elején, ami ellentmondás. Így a kisebb kör nem lehetséges. Tehát a teljes MTZ-modell

$$
\min \sum_{i=0}^{n} \sum_{j=0, j \neq i}^{n} d_{i j} x_{i j}
$$

az (1-5) feltételek mellett.

Mint említettük, az $u_{j}$ változók halmaza primitív módon írja le az idő múlását. Az idő minden lépésben egy egységgel változik. Azért nem kell $u_{0}$-t bevezetni, mert az 0-n van rögzítve. Az $u_{j}$ változók növekvő sorrendje megadja a városok látogatásainak sorrendjét. Más szavakkal, az $u_{j}$ változó jelentése a $j$ város helyzete a körútban. Vannak a TSP-nél bonyolultabb problémák, amelyek hátterében egy TSP húzódik meg. Például ütemezésnél az események időpontja nagyon fontos. Az MTZ-modell pozícióit ki lehet cserélni a modell változóiként kezelt időpontokra $[6,13]$. Az események pontos időpontjának meghatározása érdekében természetesen további feltételeket kell bevezetni.

Teherautóval a Föld felszínén szállítanak, ezért igen valószínü, hogy az útszakaszokból alkotott gráf síkbarajzolható. Az ilyen gráfoknak viszont kevés éle van.

2.1. TÉTEL. [Folklór] Tegyük fel, hogy a síkbarajzolható $G$ gráfnak sem hurokéle, sem párhuzamos élei nincsenek. Ha $G$-nek $p$ számú csúcsa és q számú éle van, akkor $q \leq 3 p-6$.

Habár az $x_{i j}$ változók száma a csúcsok számának négyzetes függvénye, ezekre a változókra csak azon élek esetében van szükség, amelyek ténylegesen léteznek a gráfban. A 2.1. Tétel szerint ezen élek száma síkgráfok esetén lineáris. Hasonlóképpen (5)-öt elegendő csak a létező élekre megkövetelni. A (2) és (3) feltételeket ehhez kell igazítani. Így jelentősen csökkenteni lehet a feladat méretét.

Legyen $G(N, A)$ egy irányított gráf hurokélek és párhuzamos élek nélkül, ahol $N$ a csúcsok, $A$ az élek halmaza. Legyen $\delta_{+}(i)$ azon élek halmaza, melyek az $i$ csúcsból indulnak. Hasonlóképp, legyen $\delta_{-}(i)$ azon élek halmaza, melyek az $i$ csúcsba mennek. Tehát $\delta_{+}(i), \delta_{-}(i) \subset A$. Ekkor (2) és (3) megfelelő alakja

$$
\forall i \in N: \sum_{(i, j) \in \delta_{+}(i)} x_{i j}=1
$$


és

$$
\forall j \in N: \sum_{(i, j) \in \delta_{-}(j)} x_{i j}=1 .
$$

(5) új alakja

$$
\forall(i, j) \in A, i, j \neq 0: u_{i}-u_{j}+n x_{i j} \leq n-1 \text {. }
$$

\section{A feladat leírása}

Egy teherautó és egy drón tandemje szállít segélyt katasztrófa után a bajbajutottaknak. Azok a helyek, amelyeket a tandemnek meg kell látogatnia, ismertek a küldetés megkezdése előtt. Lehet, hogy a teherautó nem tud minden kijelölt helyre elmenni, mert az utak sérültek. A tandem egy raktárról, más néven depóból indul, és a küldetés végén ide kell visszatérnie. A meglátogatandó helyeket egyszerüen pontoknak nevezzük. Két pont akkor van összekötve, ha van köztük olyan út, amelyen a teherautó elhaladhat, vagyis nincs jelentős kár az út ezen részén. Ha a teherautó meglátogat egy pontot, akkor a pontot a teherautó szolgálja ki. Ha egy pontot a drónnak kell kiszolgálnia, akkor egy ponton töltik fel üzemanyaggal, és ugyanott kapja meg a szállítandó csomagot. A drón a kívánt ponton ledobja a rakományt, és egy másik pontnál tér vissza a teherautóhoz. A drón maximális repülési idejét állóképességnek nevezzük. A drón az utántöltés után maximális állóképességgel rendelkezik. Egy feladat befejezése után a drón új küldetést kaphat, vagy egy ideig utazhat a teherautóval. A drón minden repülése alkalmával csak egy pontot szolgál ki. A depó is egy pont. Azon pontok kiválasztása, amelyeket a drón szolgál ki, a probléma része. A teherautó és a drón külön-külön is elhagyhatja a raktárt, és szükség esetén külön térhet vissza. A cél a küldetés befejezési idejének minimalizálása. A küldetés akkor fejeződik be, ha mindkét jármü visszatért a depóba.

\section{Az új modell}

Technikai okokból bevezetjük az $n+1$-es csúcsot, ami azonos a 0 csúccsal, tehát a raktárral. Az alábbiakban [18] jelöléseit használjuk. Legyen most $N:=$ $\{1, \ldots, n\}$. Továbbra is használjuk az $x_{i j}$ változókat, azonban azok most csak a teherautóra vonatkoznak. További jelölések: 
Paraméterek

$\pi_{i j} \quad$ a teherautó mozgásának ideje az $i$ csúcsból a $j$ csúcsba;

$p_{i j} \quad$ a drón mozgásának ideje az $i$ csúcsból a $j$ csúcsba;

$s_{w} \quad$ a drón üzemanyaggal és csomaggal való feltöltésének ideje;

$s_{d} \quad$ annak az ideje, hogy a drón egy pontra megérkezve a csomagot kézbesíti (ledobja);

$s_{t} \quad$ a teherautóról történő kézbesítés ideje, ha a teherautó megérkezett egy pontba.

Változók

$x_{i j}$ bináris változó; 1 , ha a teherautó az $i$-ből közvetlenül a $j$ csúcsba megy,

0 különben; $i \in\{0\} \cup N ; j \in N \cup\{n+1\}$;

$y_{i j} \quad$ bináris változó; 1 , ha a drón az $i$-ből közvetlenül a $j$ csúcsba megy, beleértve azt az esetet is, amikor a teherautón utazik;

0 különben; $i \in\{0\} \cup N ; j \in N \cup\{n+1\}$;

$d_{j} \quad$ bináris változó; 1 , ha a drón szolgálja ki a $j$ csúcsot; 0 különben; $j \in N$;

$w_{j}$ bináris változó; 1 , ha a drónt a $j$ csúcson feltöltik üzemanyaggal;

0 különben; $j \in\{0\} \cup N$;

$t_{j} \quad$ a $j$ csúcs kiszolgálásának befejezési időpontja, nem beleértve a drón esetleges feltöltését és egy további csúcs kiszolgálását; $j \in N \cup\{0, n+1\}$;

$\varepsilon \quad$ a drón állóképessége;

$M \quad$ egy nagy pozitív szám.

A síkgráfokkal kapcsolatban bevezetett fogalmakat a modell matematikai megfogalmazásában használjuk. Feltehető azonban, hogy a drón bármelyik két pont között repülhet.

A körút a raktárból indul és visszatérve ott ér véget. A teherautóra vonatkozóan ez azt jelenti, hogy

$$
\sum_{(0, j) \in \delta_{+}(0)} x_{0 j}=1
$$

és

$$
\sum_{(i, n+1) \in \delta_{-}(n+1)} x_{i, n+1}=1 .
$$

Minden más csúcs esetében a csúcsba való érkezések és a csúcsból való távozások számának azonosnak kell lennie:

$$
\forall j \in N: \sum_{(i, j) \in \delta_{-}(j)} x_{i j}=\sum_{(j, i) \in \delta_{+}(j)} x_{j i} .
$$

Hasonló feltételek vonatkoznak a drónra is:

$$
\sum_{j=1}^{n} y_{0 j}=1
$$


és

$$
\sum_{j=1}^{n} y_{j, n+1}=1
$$

Itt is minden más csúcs esetében a csúcsba való érkezések és a csúcsból való távozások számának azonosnak kell lennie:

$$
\forall j \in N: \sum_{i=0, i \neq j}^{n} y_{i j}=\sum_{i=1, i \neq j}^{n+1} y_{j i} .
$$

Minden csúcsot legalább a tandem egyik tagjának meg kell látogatnia:

$$
\forall j \in N: \quad \sum_{(i, j) \in \delta_{-}(j)} x_{i j}+\sum_{i=0, i \neq j}^{n} y_{i j} \geq 1 .
$$

Minden csúcsot vagy a teherautó, vagy a drón szolgál ki. Az utóbbi azt jelenti, hogy a drón ott ledobja a csomagot:

$$
\forall j \in N: \sum_{(i, j) \in \delta_{-}(j)} x_{i j}=1-d_{j} .
$$

Ha a drónt egy adott ponton feltöltik üzemanyaggal, akkor ezt a pontot a teherautó ki tudja szolgálni:

$$
\forall j \in N: w_{j}+d_{j} \leq 1
$$

Ha a drón az $i$ csúcsból a $j$ csúcsba repül, és kiszolgálja a $j$ csúcsot, akkor az $i$ csúcsban fel kell tölteni:

$$
\forall i \in\{0\} \cup N: \forall j \in N: j \neq i: y_{i j}+d_{j} \leq 1+w_{i}
$$

Induláskor a raktár, azaz a 0 csúcs kiszolgálása a 0 időpontban fejeződik be:

$$
t_{0}=0
$$

Egy pont kiszolgálása vagy akkor fejeződik be, amikor a tandem mindkét tagja megérkezett és a kiszolgálás is megtörtént; vagy, ha a tandem egyik tagja nem látogatja meg a pontot, akkor a kiszolgálás befejezési ideje nem függ ettől a jármütől. Ha a teherautó szolgálja ki a pontot, akkor az előző pont kiszolgálása után szükség esetén még ott fel kell töltenie a drónt, át kell mennie a következő pontba, és ott le kell szállítania a segélycsomagot. Ebből a következő feltételt kapjuk:

$$
\forall j \in N: \forall i \in\{0\} \cup N, i \neq j: t_{j} \geq t_{i}+s_{w} w_{i}+\pi_{i j}+s_{t}-M\left(1-x_{i j}\right) .
$$


A $j=n+1$ esetén a feltétel hasonló, de mivel a raktárt nem kell kiszolgálni, $s_{t}$ kikerül belőle:

$$
\forall i \in N: t_{n+1} \geq t_{i}+s_{w} w_{i}+\pi_{i, n+1}-M\left(1-x_{i, n+1}\right) .
$$

A drónra vonatkozó feltétel nagyon hasonló. Az utazási idő és a kiszolgálás ideje különböző:

$$
\forall j \in N: \forall i \in\{0\} \cup N, i \neq j: t_{j} \geq t_{i}+s_{w} w_{i}+p_{i j}+s_{d} d_{j}-M\left(1-y_{i j}\right) .
$$

Ismét $j=n+1$ esetén egyszerüsödik a feltétel:

$$
\forall i \in N: t_{n+1} \geq t_{i}+p_{i, n+1}-M\left(1-y_{i, n+1}\right) .
$$

A drón által végzett minden kiszolgálás két részből áll. A drón egy $i$ pontból, a teherautóról indul, a $j$ pontra repül, azt kiszolgálja, és onnan repül tovább a $k$ pontra, ahol találkozik a teherautóval. Az egész repülés, beleértve a segélycsomag ledobását, nem lehet hosszabb, mint az állóképesség:

$$
\forall j \in N: \sum_{i=0, i \neq j}^{n} p_{i j} y_{i j}+\sum_{k=1, i \neq j}^{n+1} p_{j k} y_{j k}+s_{j} d_{j}-M\left(1-d_{j}\right) \leq \varepsilon .
$$

A célfüggvény a körút bejárási idejének minimalizálása, azaz

$$
\min t_{n+1} \text {. }
$$

A feladat feltételeinek vannak egyszerü következményei, melyeket az alábbi két lemmában adunk meg.

4.1. SEGÉDtÉTEL. A (13) és (14) feltételből következik, hogy

$$
\forall j \in N: \sum_{i=0, i \neq j}^{n} y_{i j} \geq d_{j}
$$

Bizonyítás. A bizonyítás egyszerű helyettesítés.

(21) jelentése az, hogy ha a $j$ pontot a drón szolgálja ki, vagyis a drón ott segélycsomagokat dob le, akkor a drónnak oda kell repülnie ehhez a ponthoz.

4.2. SegÉdtétel. A (15) és (16) feltételből következik, hogy

$$
\forall i \in N: \forall j \in N: j \neq i: y_{i j}+d_{i}+d_{j} \leq 2 .
$$

Bizonyítás. A bizonyítás (15) és (16) összegzéséből áll.

A lemma értelmében a drón nem dobhat le segélycsomagot a repülés két végpontján.

A legfontosabb azonban annak megmutatása, hogy a modell korrekt. 
4.3. SEgÉDtétel. Ha a drón az $i$ pontról a $j$ pontra repül, kiszolgálja azt, és onnan a $k$ pontra repül tovább, ahol $i, j$ és $k$ páronként különböző pontok, akkor a teherautó szintén meglátogatja a $k$ pontot, és nem távozhat a drón elött.

Bizonyítás. A (12) feltétel azt mondja, hogy ha a drón a $j$ pontra repül, akkor tovább kell repülnie egy másik pontra, vagyis létezik $k$ pont. Ebből következik a 4.2. segédtétel szerint, hogy ha a drón a $j$ pontra repül és kiszolgálja, akkor nem tudja kiszolgálni a következő pontot, vagyis a $k$ pontot. Ha a $k$ pontot nem a drón szolgálja ki, akkor a (14) feltétel azt jelenti, hogy a teherautónak meg kell látogatnia a $k$ pontot. A $k$ pont kiszolgálása csak akkor fejeződik be, a (18) és (19) feltételek szerint, ha a teherautó és a drón is megérkezett, és a teherautó kiszolgálta a pontot.

\section{Mi az új a modelben?}

[18] modellje 37 típusú feltétellel és két célfüggvénnyel rendelkezik. Az egyik célfüggvény megegyezik a (20)-beli függvénnyel. Ez a modell a drón repülését háromindexü bináris változókkal írja le. Így $O\left(n^{3}\right)$ változóval rendelkezik. Azzal sikerült az ilyen típusú változók számát $O\left(n^{2}\right)$-re redukálni, hogy a modellben nem csupán a drónok repülését értelmezzük mozgásukként, hanem azt is, amikor a teherautón utaznak. Így az $y_{i j}$ változók egy teljes körutat írnak le az $x_{i j}$ változókhoz hasonlóan, lásd a (10-12) feltételeket. Bár a két körút számos közös élt tartalmazhat, pontosan ott, ahol drón a teherautón utazik, de különbözők, ha a drón legalább egy repülést teljesít. Ezzel a drón küldetéseinek időpontjaira vonatkozó feltétel is feleslegessé vált.

[18] modellje ugyancsak feleslegesen tartalmaz mind pozíció-, mind időváltozókat. A pozícióváltozók a [10] modelljéből származnak, ahol az idő leegyszerüsített leírására szolgálnak [4] modelljével ellentétben, ami semmi időre vonatkozó információt nem tartalmaz azon az áron, hogy feltételeinek száma exponenciális. Ha azonban az időre vonatkozóan pontosabb eredményekre van szükség, mint az egyes helyek felkeresésének sorrendje, akkor az időpontok leírására külön változókat kell bevezetni, és a pozícióváltozók, mint ebben az esetben is, teljesen kiküszöbölhetők.

A kapott modell a katasztrófa utáni, folyamatosan változó helyzetben ismételten megoldható a soron következő szállítás optimalizálására.

\section{Köszönetnyilvánítás}

A szerzők köszönetet mondanak Fereshte Nadjenadnak, hogy felhívta figyelmüket a téma fontosságára. 


\section{Hivatkozások}

[1] N. Agatz, P. Bouman and M. Schmidt: Optimization Approaches for the Traveling Salesman Problem with Drone, Transportation Science, Vol. 52 No. 4, pp. 965-981 (2017). DOI: $10.1287 / \operatorname{trsc} .2017 .0791$

[2] P. Bouman, N. Agatz And M. Schmidt: Dynamic programming approaches for the traveling salesman problem with drone, Networks, Vol. 72, pp. 528-542 (2018).

DOI: $10.1002 /$ net.21864

[3] N. Boysen, D. Briskorn, S. Fedtke and S. Schwerdfeger: Drone delivery from trucks: Drone scheduling for given truck routes, Networks, Vol. 72, pp. 506-527 (2018). DOI: $10.1002 /$ net.21847

[4] G.B. Dantzig, D.R. Fulkerson And S.M. Johnson: Solution of a large scale traveling salesman problem, Operations Research, Vol. 2, pp. 393-410 (1954). DOI: 10.1287 /opre.2.4.393

[5] S.M. Ferrandez, T. Harbison, T. Weber, R. Sturges and R. Rich: Optimization of a Truck-drone in Tandem Delivery Network Using K-means and Genetic Algorithm, Journal of Industrial Engineering and Management, Vol. 9 No. 2, pp. 374-388 (2016).

DOI: $10.3926 /$ jiem.1929

[6] H. Gültekin, O.E. Karasan and M.S. Aktürk: Pure Cycles in Flexible Robotic Cells, Computers and Operations Research, Vol. 36 No. 2, pp. 329-343 (2009).

DOI: $10.1016 /$ j.cor.2007.10.007

[7] Q.M. Ha, Y. Deville, Q.D. Pham AND M.H. Ha: A hybrid genetic algorithm for the traveling salesman problem with drone, Journal of Heuristics, megjelenés alatt (2019). DOI: $10.1007 / \mathrm{s} 10732-019-09431-y$

[8] A.M. HАM: Integrated scheduling of $m$-truck, $m$-drone, and $m$-depot constrained by timewindow, drop-pickup, and m-visit using constraint programming, Transportation Research Part C: Emerging Technologies, Vol. 91, pp. 1-14 (2018). DOI: 10.1016/j.trc.2018.03.025

[9] X-H. Li And J-Ch. Zheng: Efficient Post-Disaster Patient Transportation Transfer: Experiences and Lessons Learned in Emergency Medical Rescue in Aceh After the 2004 Asian Tsunami, Military Medicine, Vol. 179 No. 8, pp. 913-919 (2014).

DOI: 10.7205/MILMED-D-13-00525

[10] C.E. Miller, A.W. Tucker And R.A. Zemlin: Integer programming formulation of traveling salesman problems, Journal of the ACM, Vol. 7 No. 4, pp. 326-329 (1960).

DOI: $10.1145 / 321043.321046$

[11] C.C. Murray And A.G. Chu: The flying sidekick traveling salesman problem: Optimization of drone-assisted parcel delivery, Transportation Research Part C: Emerging Technologies, Vol. 54, pp. 86-109 (2015). DOI: 10.1016/j.trc.2015.03.005

[12] A. Nedjati, Vizvári B. And G. IzBirak: Post-earthquake response by small UAV helicopters, Natural Hazards, Vol. 80, pp. 1669-1688 (2016). DOI: 10.1007/s11069-015-2046-6

[13] M.G. NeJAd, H. Güden And VizvÁRI B.: Time minimization in flexible robotic cells considering intermediate input buffers: a comparative study of three well-known problems, International Journal of Computer Integrated Manufacturing, Vol. 32 No. 8, pp. 809-819 (2019). DOI: 10.1080/0951192X.2019.1636411 
[14] B.F. Voigt: Der Handlungsreisende wie er sein soll und was er zu thun hat, um Aufträge zu erhalten und eines Glücklichen Erfolgs in seinen Geschaften gewiss zu sein, CommisVoageur, Ilmenau (1832).

[15] A. Orman and H.P. Williams: A survey of different integer programming formulations of the travelling salesman problem, Optimization, Econometric and Financial Analysis, pp. 91-104 (2007). DOI: $10.1007 / 3-540-36626-1 \_5$

[16] B. SAH: Drone Truck Combined Operation: Models and Algorithm, PhD Thesis, Department of Industrial and Systems Engineering, Binghamton University, State University of New York (2019).

[17] https://en.wikipedia.org/wiki/2011_Van_earthquakes

[18] K. WANG, B. YUAN, M. ZhaO AND Y. Lu: Cooperative route planning for drone and truck in delivery services: A bi-objective optimisation approach, Journal of the Operational Research Society, Vol. 71 No. 10, pp. 1657-1674 (2019).

DOI: $10.1080 / 01605682.2019 .1621671$

[19] E.E. YureK And H.C. Ozmutlu: A decomposition-based iterative optimization algorithm for traveling salesman problem with drone, Transportation Research Part C, Vol. 91, pp. 249-262 (2018). DOI: 10.1016/j.trc.2018.04.009

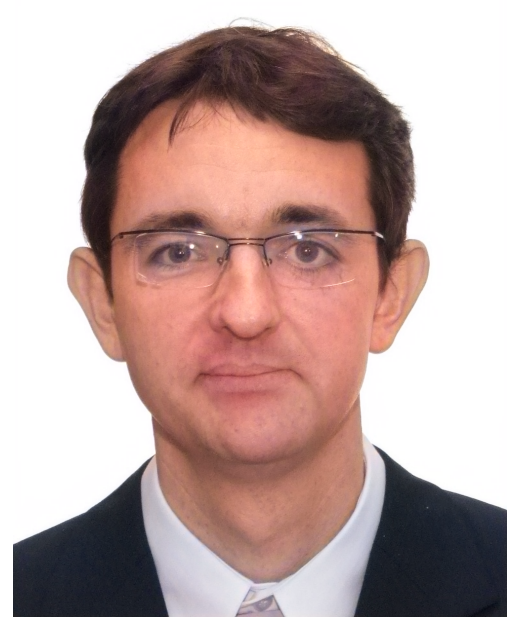

Kovács Gergely 1975-ben született. Doktori címét az Eötvös Loránd Tudományegyetemen szerezte 2006-ban. Jelenleg a tatabányai Edutus Egyetem főiskolai tanára. Kutatási területe a termelésütemezés, modellalkotás, digitális geometria. Eddig közel 20 tudományos cikke jelent meg, több egyetemi jegyzetet írt.

\section{KOVÁCS GERGELY}

Edutus Egyetem, Tatabánya kovacs.gergely@edutus.hu

\section{VIZVÁRI BÉLA}

Department of Industrial Engineering, Eastern Mediterranean University Famagusta, Észak-Ciprus bela.vizvari@emu.edu.tr 


\section{TRANSPORTATION OF RELIEF ITEMS AFTER DISASTER BY A TRUCK-DRONE TANDEM}

\section{Gergely KovÁcs, Béla Vizvári}

Humanitarian logistics encompasses all branches of logistics that are done to help people. Within humanitarian logistics, an important sub-area is the delivery of relief items to those in need in a post-disaster period. With the change in transport technology, new mathematical problems arise here. At present, the key technology innovation is the use of unmanned aerial vehicles (drones). In this paper, we discuss a version of the traveling salesman problem in which a truck and a pair formed by a drone meets the needs of a disaster-stricken rural area, i.e. a non-metropolitan area with a dense road network. Between the two flights of the drone, a truck takes the drone with itself. The drone is loaded from the aid packages delivered on the truck. The truck itself serves all the points it passes through. Two important advantages of this solution are that it is possible to provide places that cannot be reached otherwise due to road damage or other reasons, and the shorter time can deliver aid to those in need.

Keywords: TSP; TSP-D; humanitarian logistics; disaster; post-disaster period

Mathematics Subject Classification (2000): 90-10, 90B20 